\title{
THE FOREIGNER AND THE RIGHT TO JUSTICE IN THE AFTERMATH OF SEPTEMBER $11^{\text {th }}$
}

\author{
François Crépeau \\ Professor of International Law \\ Scientific Director, Centre for International Studies (CÉRIUM) \\ University of Montreal
}

May 12, 2005

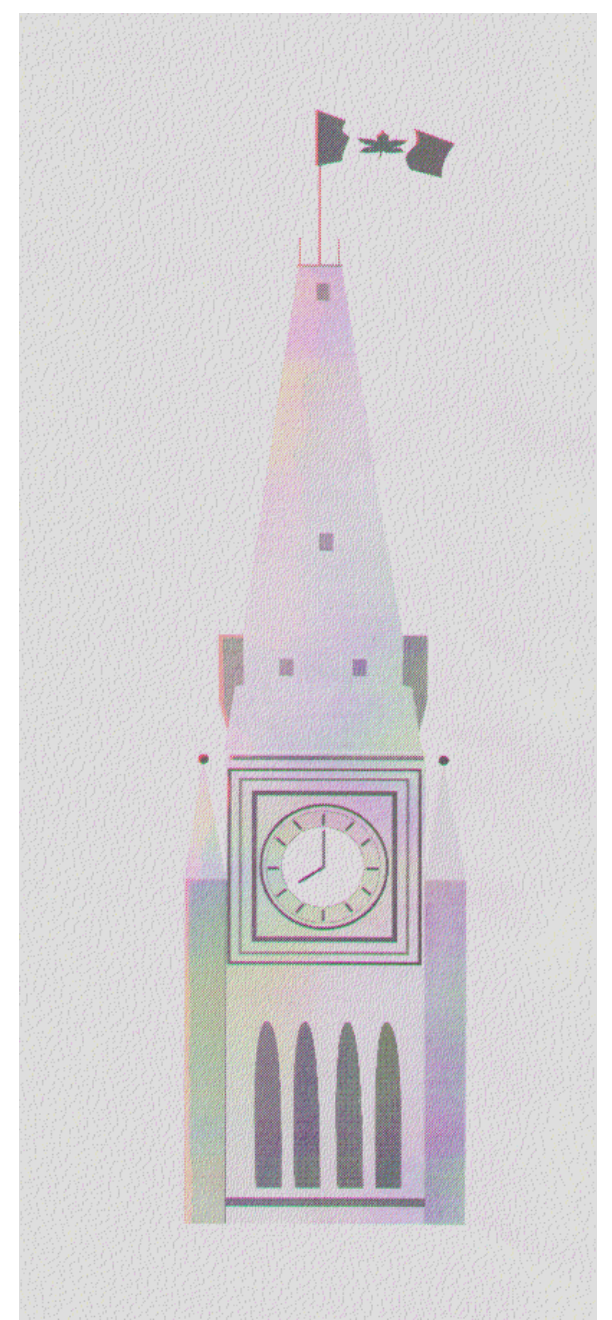

Breakfast on the Hill Seminar Series

Sponsored by:

Canadian Federation for the Humanities and Social Sciences, 415-151 Slater Street

Ottawa, Ontario K1P 5 H3 (613) 238-6112 www.fedcan.ca

The Federation thanks the Social Sciences and Humanities Research Council of Canada for its support. 
In January 2003, the Privacy Commissioner of Canada stated in his report for 2001-2002, to the Parliament, that ${ }^{1}$ :

The Government is, quite simply, using September 11 as an excuse for new collections and uses of personal information about all of us Canadians that cannot be justified by the requirements of anti-terrorism and that, indeed, have no place in a free and democratic society...

Now I am informing Parliament that there is every appearance that governmental disregard for crucially important privacy rights is moving beyond isolated instances and becoming systematic. This puts a fundamental right of every Canadian profoundly at risk. It is a trend that urgently needs to be reversed...

Regrettably, this Government has lost its moral compass with regard to the fundamental human right of privacy.

These are extremely hard words, when expressed by an officer of Parliament with a majority Government in the House. The Commissioner was referring to various acts or draft legislations of the government, all prepared in the aftermath of September $11^{\text {th. }}$

- Canada Customs and Revenue Agency's new passenger database;

- the unrestricted access by Royal Canadian Mounted Police (RCMP) to all information that airline companies collect on their passengers and its transfer to foreign authorities under the Aeronautics Act $^{2}$;

- dramatically enhanced state powers to monitor our communications, especially international ones;

- a possible national ID card with biometric identifiers, as advanced by the Citizenship and Immigration Minister, on the model of that which has already been adopted for permanent residents; and

1 Privacy Commissioner of Canada, News Release, Jan. 29, 2003, available at: http://www.privcom.gc.ca/media/nr-c/2003/02_05_b_030129_e.asp?V=Print.

2 Act to amend the Aeronautics Act., S.C. 2001, Chapter 38 (Bill C-44). Assented Dec. 18, 2001, available at: http://www.parl.gc.ca/37/1/parlbus/chambus/house/bills/government/C-44/C-44_3/C44 cover-F.html. See: Office of the Privacy Commissioner of Canada, Press Release, Nov. 30, 2001. 
- the Government's support of precedent-setting video surveillance of public streets by the RCMP.

Many of these measures would have never been accepted a decade ago. Why are considered acceptable today?

A reason for this may be found in the fear of terrorism, exacerbated by the wars in Afghanistan and Iraq and also, up until recently, by the failure of the Middle East Road Map. There is another element of explanation which is not mentioned in official documents: in our collective mind, the persons who are targeted by anti-terrorist measures are essentially foreigners.

« If you have nothing to hide, you have nothing to be afraid of »: this is the McCarthyist argument which is put forward everywhere by those who justify drastic measures taken in the fight against terrorism. According to them, the new measures will provide effective protection for good citizens who respect the laws from all these foreigners 'who hate us'.

The classical rhetoric of the distinction between "them" and "us" is operating here. The deterioration of the rights of foreigners in Canada, as in other western countries, originates from the idea that, when security is at stake, a foreigner should not necessarily enjoy the same fundamental rights as the citizen.

This breach of the fundamental dignity of the person does not seem to be objected to by a large majority of our population, even if it has devastating consequences for the individuals and their families, as long as these persons are foreigners.

In effect, on purely moral grounds, it is somewhat difficult to reconcile the wave of sympathy created by the Maher Arar affair with the almost total indifference, if not hostility, with which most foreigners are sent back to a potentially similar fate.

What is at stake here is the fate of foreigners who risk their freedom, their security or their life when returned home, or simply the fact that they may be detained or deported on very slim basis. Is also at stake the fate of their families in Canada. Individuals are uprooted, families may be separated, children may be wrenched from the only world they have ever known. Decisions having such consequences should be carefully monitored.

I shall first illustrate the erosion of foreigners' rights, during the last decade and especially as it is related to the current security agenda, and then underline the fact that 
foreigners are not anymore considered as persons necessarily deserving of justice and dignity.

\section{THE EROSION OF FOREIGNERS' RIGHTS IN CANADA}

During the 1990s, immigration entered what Didier Bigo called the paradigm of internal security. Immigration was considered more and more as an issue related to criminality ${ }^{3}$.

After the events of September $11^{\text {th }}$, the fear of terrorism led to the adoption of many new anti-terrorist measures and a reinforcement of the security-related policy apparatus in Canada and elsewhere. Immigration had entered the realm of national security.

On October 12, 2001, the Minister of Citizenship and Immigration announced immigration measures to be integrated in the new anti-terrorist strategy. ${ }^{4}$

Two months later, the Canadian and U.S. governments issued the Joint Statement on Cooperation and Regional Migration Issues and the 30-point Action Plan for Creating a Secure and Smart Border. ${ }^{5}$ Under these instruments, Citizenship and Immigration Canada enjoys primary responsibility, on Canada's part, for ten initiatives, among which are:

- Administering the processing of refugees and asylum-seekers, including screening for security or criminal risks and sharing information;

- Managing claims for refugee status and asylum, including by negotiating an agreement to manage the flow at land borders of individuals seeking asylum;

3 Didier Bigo, L'Europe des polices et de la sécurité intérieure, Paris : Complexe, 1992.

4 Citizenship \& Immigration Canada, Strengthened Immigration Measures To Counter Terrorism, Oct. 12, 2001, available at: http://www.cic.gc.ca/english/press/01/0119-pre.html. The funds allocated to anti-terrorist measures between 2001 and 2007 were then estimated at 7.7 billion Canadian dollars: OFFICE of the Auditor General of CANADA, Citizenship AND IMMigration CANADA, CONTROL AND ENFORCEMENT, Apr. 2003 Report, Chapter 5, available at: http://www.oagbvg.gc.ca/domino/reports.nsf/html/20030405ce.html

5 Canada-U.S. Smart Border Declaration, signed Dec. 12, 2001 by John Manley, Minister of Foreign Affairs and International Trade (Canada), and Tom Ridge, Director of the Office of Homeland Security (U.S.), available at: http://dfait-maeci.gc.ca/anti-terrorism/can-us-border-en.asp 
- Developing compatible immigration databases, by automating existing exchanges of lookout information and developing parallel immigration databases for regular information exchange.

Many of these measures are perfectly understandable improvements on previous practice. They are a necessary tool in the fight against international criminal activities, such as terrorism.

However, it is clear that they do not aim at protecting more individuals from persecution in their home country. On the contrary, efficient border management includes making sure that fewer persons will be able to reach the border and ask for protection. No provision is made in these instruments for more fully-fledged implementation of the 1951 U.N. Convention relating to the Status of Refugees or other human rights obligations.

Indeed, we shall see that they may infringe upon the fundamental rights and freedoms of foreigners in ways that we would not deem acceptable if they were applied to ourselves as citizens in Canada or to Canadian citizens abroad by foreign authorities.

\subsection{Elimination of appeals available to foreigners}

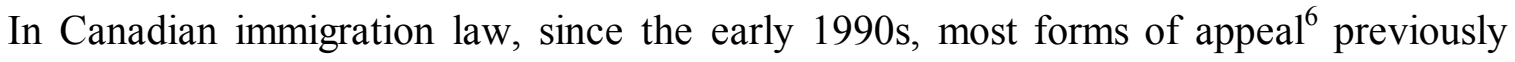
available to foreigners have been eliminated. Furthermore, one can obtain judicial review only after having obtained leave to apply for it. Judicial review is no longer de jure. The management of immigration files is certainly speedier, maybe more efficient, but human rights protection has been radically diminished. Since 2002, even Canadian sponsors of foreigners found to be inadmissible on grounds of "security, violating human or international rights, serious criminality or organized criminality" have been deprived of any right to appeal.

6 For example, the new 2002 Immigration and Refugee Protection Act removes all right of appeal and power to review removal orders against any person, even a permanent resident, who is inadmissible on the grounds of security, violating human or international rights, serious criminality and organized criminality. See s. 64 of the Immigration and Refugee Protection Act, S.C. 2001, Chapter 27, available at: http://laws.justice.gc.ca/en/I-2.5/text.html. 


\subsection{Reduction of legal aid}

The Canadian refugee determination system is considered one of the best in the world. Ministers like to say that Canada has "the Cadillac" of the refugee determination systems. Based on the Canadian Charter of Rights and Freedoms, this system is quasi-judicial and each refugee claimant has the right to a hearing with full interpretation and the right to counsel. However, it has never been deemed important, in Canadian law and policy, to provide sufficient legal aid to help refugees prepare their case. Although the refugee determination system is of federal jurisdiction, legal aid in such matters has been left to the provincial legal aid schemes without insuring some equalization. In Ontario, the average legal aid fee for a refugee determination case is still over CAN\$1500. In Quebec, it is CAN\$455, which represents three hours of work, if an interpreter is not required. In British Columbia, legal aid for refugee determination cases was totally eliminated in June 2003, although further negotiations resulted in the re-introduction of a limited service in March 2004. The importance of legal aid in criminal cases has been underscored, in order to help accused persons to defend themselves properly and ensure the legitimacy of any subsequent guilty verdict. If the worst mafia boss has a right to legal aid, why is it that, in refugee cases, when the consequences of an erroneous decision can be death, torture or prison, the provision of legal aid is not thought equally important?

\subsection{Increased powers of detention}

Although Canada's detention practice is not as harsh as what can be seen in other countries such as the United States, the detention of undocumented asylum seekers has increased considerably in the past years. This increased detention was a policy objective announced by the minister.

For example, the Immigration and Refugee Protection Act has a provision allowing an officer to arrest and detain a foreigner without warrant where he or she "has reasonable grounds to suspect that the permanent resident or the foreign national is inadmissible on grounds of security": such a possibility is open if the officer determines, inter alia, that the arrest and detention of the person in question is necessary to prevent the carrying out 
of a terrorist activity. ${ }^{7}$ The normal level of evidence in such matters is that the officer must "believe on reasonable grounds" that a criminal activity will be committed. How low is the threshold of the "suspicion on reasonable grounds"? What is a suspicion based on unreasonable grounds? These questions remain to be answered by Canadian courts ${ }^{8}$.

During the summer of 2003, some twenty persons, most of them Pakistani or Indian citizens studying in Canada, were arrested without warrant. There was a suggestion that they might have constituted a sleeper cell for Al-Qaeda. This suggestion was based on such information as their being registered in a flying school, or being registered with a now defunct business school, or having two different residential addresses in order to avoid paying higher auto insurance premiums, or having documents measuring the $\mathrm{CN}$ tower in Toronto. Most of them have been released on bail. The Immigration and Refugee Board Member who authorized their release noted that the activities deemed suspect were not special or unusual among potential new immigrants. ${ }^{9}$

\subsection{Easier use of security certificates}

Security certificates, as an instrument for removing foreigners who pose a threat to the security of Canada, on grounds of security, or on grounds of a violation of human rights or international law, serious criminality or organized criminality, have been available under Canadian immigration legislation since 1991.

Foreign nationals who are the subject of a security certificate are automatically detained. If the judge determines that the certificate is unreasonable, the certificate is quashed. If, however, the judge decides that it is reasonable, it is considered conclusive proof that the foreign national named in it is inadmissible. This is the case despite the fact that the foreigner has not had access to most of the evidence.

\footnotetext{
$7 \quad$ Immigration and Refugee Protection Act, s. 55(3) and 34.

8 See: Kent Roach, “Canada's Response to Terrorism”, (soon to be published).

9 Canadian Council for Refugees, CCR denounces detention based on suspicion (Media release:
} Sept. 2, 2003), available at: http://www.web.net/\%7Eccr/20detained.html. 
The Immigration and Refugee Protection Act increased the effect of security certificates, by providing for suspension or termination of a claim for protection as refugee upon their issuance, by making broader provision for their issuance in relation to organized crime, by eliminating appeals, by preventing any access to Pre-Removal Risk Assessment and by streamlining the removal process ${ }^{10}$.

Specific procedures designed to deal with very sensitive information such as security intelligence are essential in any legal system and provisions have been recently added to the Criminal Code that deal with security issues, allowing for example some of the evidence to remain secret if a judge determines that this can be done without jeopardizing justice in the criminal proceedings involved ${ }^{11}$.

However, a procedure providing for a person to be sent back to their country, eventually to persecution or torture, without knowing on what factual basis such an order is issued, seems completely arbitrary.

Solutions to this real dilemma exist and some imagination has to be exercized here. For example, some have suggested that a small number of defence lawyers could be given full security clearance, be obliged to take a special oath of office and be assigned to the defence of foreigners under security certificates. They would thereafter be allowed to see the whole of the evidence against their client - although not to communicate it to their client - and would therefore be in a position to defend their client adequately ${ }^{12}$.

The legitimacy of the whole security certificate system is at stake.

\subsection{Aggravated sanctions for human smuggling}

10 See Immigration and Refugee Protection Act, ss.77, 81, 115; Citizenship \& Immigration Canada, Keeping Canada Safe, Factsheet no 6, July 7, 2002, available at: http://www.cic.gc.ca/english/irpa/fskeeping.html.

11 See: Kent Roach, “Canada's Response to Terrorism”, (soon to be published).

12 See: Kent Roach, “Canada's Response to Terrorism”, (soon to be published). 
Canada was among the first nations to sign the 2001 United Nations Convention against Transnational Organized Crime ${ }^{13}$ and its two accompanying Protocols, including the Protocol against the Smuggling of Migrants by Land, Sea and Air. Consequently, the new Immigration and Refugee Protection Act, which came into force in June 2002, modified the penalty for migrant smuggling. The Immigration and Refugee Protection Act imposed tougher maximum penalties for organizing an illegal entry into Canada, and very severe penalties for the new offence of human trafficking, but did not distinguish, as did the Protocol, between persons who are motivated by humanitarian concerns and others. ${ }^{14}$ Someone who helps a family member flee persecution can be refused a refugee claim hearing or lose permanent residence without the possibility of appeal. Helping ten persons or more to cross the border illegally, without any threat to persons or property, is now an offence punishable by life imprisonment. This is more than the punishment for rape at gunpoint, which carries a maximum sentence of fourteen years. It is the same punishment as that imposed for an act of genocide or a crime against humanity. ${ }^{15}$ Who can seriously equate a nazi leader with a small migrant smuggler? What subconscious fear of the foreigner is expressed when the scale of penalties is distorted in such a blatant manner?

\subsection{Safe Third Country Agreement}

13 United Nations Convention against Transnational Organized Crime, G.A. res. 55/25, annex I, 55 U.N. GAOR Supp. (No. 49) at 44, U.N. Doc. A/45/49 (Vol. I) (2001), entered into force: Sept., $29,2003$. Available

at: http://www.uncjin.org/Documents/Conventions/dcatoc/final_documents_2/convention_eng.pdf.

14 Estibalitz Jimenez and François Crépeau, "The Immigration and Refugee Protection Act", 5 Horizons, Bulletin of Canadian Policy Research Initiative $\mathrm{n}^{\circ} 2$, Sept. 2002. Available at: http://policyresearch.gc.ca/page.asp?pagenm=v5n2_art_08.

15 See: Art. 272, Criminal Code of Canada, R.S. 1985, Chapter C-46; Art. 4 and 6, Crimes Against Humanity and War Crimes Act, S.C. 2000, Chapter 24. 
Canada and the U.S. signed a Safe Third Country Agreement in December 2002. ${ }^{16}$ This agreement will allow each country to send back to the other all the asylum seekers that have reached the territory of the former by way of the territory of the latter. Figures provided by Citizenship \& Immigration Canada (CIC) indicate that from 1995 to 2001, approximately one-third of all refugee claims in Canada were made by claimants known to have arrived from or through the U.S. Of those claiming refugee status at a port of entry (at an airport or border post), where verification of transit countries may be more easily undertaken, $60 \%$ to $70 \%$ came from or through the U.S. on their way to Canada. No one seems to be able to provide hard data regarding the flow of refugee claimants from Canada to the U.S., but it appears to be less than a few hundred per year. ${ }^{17}$

Such international cooperation is in principle desirable: it would be to the advantage of refugees if States cooperated to better protect them. However, in this case, one may question the basic premise that the U.S. is a "safe" country for all asylum seekers. $\mathrm{NGOs}^{18}$ and the United Nations High Commissioner for Refugees expressed concerns about certain U.S. practices, especially in the fields of detention procedures and the expedited removal process. Canada is therefore preventing foreigners in the U.S. to ask for asylum in Canada, in the full knowledge that they will not be treated in a similar way than they could expect to be treated in Canada.

16 Citizenship \& Immigration Canada, Canada and U.S. Negotiators Agree to Final Draft Text of Safe Third Country Agreement. Available at: http://www.cic.gc.ca/english/policy/safe-third.html.

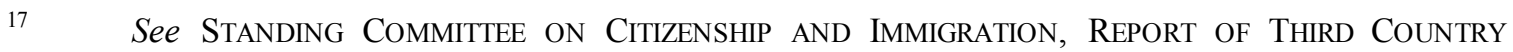
REGULATIONS, Dec. 2002, available at: http://www.parl.gc.ca/InfoComDoc/37/2/CIMM/Studies/Reports/cimmrp01/03-cov-e.htm; Speech of the Minister of Foreign Affairs to the Public Policy Forum Conference on Managing our Border with the United States (Toronto, 28 November 2001), text available at: http://webapps.dfaitmaeci.gc.ca/minpub/Publication.asp?publication_id=378840\&Language=E; US COMMITTEE FOR REFUGEE, WORD REFUGEE SURVEY 2003 UNITED STATES REPORT, available at: http://www.refugees.org/world/countryrpt/amer_carib/2003/united_states.cfm.

18 Canadian Council For Refugees, 10 Reasons Why The Us-Canada Refugee Deal Is A Bad Idea, available at: http://www.web.net/\%7Eccr/10reasons.html. 
By deciding to return asylum seekers to the U.S., Canada reduces by a third the caseload of the Immigration and Refugee Board (IRB). In doing so, however, Canada deprives these persons of a refugee determination system based on the Canadian Charter of Rights and Freedoms that has no equivalent in the U.S. It is common knowledge that the American refugee determination system has been downgraded, especially at the level of the U.S. Board of Immigration Appeals ${ }^{19}$. And the perception is that, regarding certain nationalities, the American system is not fair, which explains why many were seeking protection from Canada.

It is also predictable that the implementation of such policies is creating a huge market for migrant smugglers to help people cross the border undetected before asking for refugee status inside Canada. This will further degrade the image of asylum seekers, in effect turning them, in the court of public opinion, into the menacing figures of international criminals. Harsher repressive or deterrent measures against them would then be made possible.

\subsection{Interception measures beyond State borders}

Canada's Immigration and Refugee Protection Act has several provisions that make carriers responsible for the removal costs of passengers arriving at Canadian airports with improper documents. ${ }^{20}$ Under the Immigration and Refugee Protection Act, the Department of Citizenship and Immigration charges a carrier an administration fee for each traveller arriving with improper documents. The Department has signed agreements with most airlines flying regular routes into Canada. According to the agreements, carriers with good performance records in deterring these travellers from arriving in Canada pay reduced administration fees. Airlines, in turn, agree that immigration control officers will train their staff and assist them at foreign airports in identifying passengers

U.S. Committee for Refugees, Word Refugee survey 2003 United States Report, available at: http://www.refugees.org/world/countryrpt/amer_carib/2003/united_states.cfm

20 See s. 148(1)(a) of the Immigration and Refugee Protection Act and s. 279(1) of the Immigration and Refugee Protection Regulations; Citizenship \& Immigration Canada, Guide For Transporters, 2002, available at: http://www.cic.gc.ca/english/pdf/pub/transporters.pdf. 
with improper travel documents. ${ }^{21}$ All these measures aim to enhance the efficiency of interception of undocumented foreigners before their arrival at the Canadian border. The practices developed for controlling papers at foreign airports can respect very thorough guidelines, or they may be blatantly discriminatory: in either case, their control by Canadian tribunals or other reliable external third party is inexistent.

Controlling the actions of Canadian immigration or intelligence services overseas is extremely difficult. Even if thousands of immigration files are processed annually and systematic discrimination is alleged, little can really be done. As in most western countries, Canadian authorities have adopted systematic policies for the interception and interdiction of irregular migrants outside of Canadian territory and international cooperation in this field is very active. ${ }^{22}$ Canada maintains that it will respect its international obligations towards the protection of refugees and human rights generally, but nothing in the Canadian Government's interception and interdiction policies provides for effective means of allowing the irregular migrants in real need of protection to come to Canada. Judicial control of such policies, based on the Canadian Charter of Rights and Freedoms, is improbable at present.

\section{THE FOREIGNER, EVEN AT RISK, IS PERCEIVED AS A SECURITY THREAT}

The foreigner is not considered anymore as a person who, as a matter of principle, always deserves justice, and therefore dignity.

Foreigners do not benefit from the immediate sympathy of public opinion. They have no proper political representation. Some say that they are not part of the social compact. They may be feared from start. Political antipathy towards foreigners can easily be built and all social institutions, courts included, can be influenced by such sentiments. Most human rights, however, are not conditional upon membership in any social compact:

\footnotetext{
21 Office of the Auditor General of CAnada, Citizenship \& Immigration Canada, Control

AND ENFORCEMENT, Apr. 2003 Report, Chapter 5, available at: http://www.oagbvg.gc.ca/domino/reports.nsf/html/20030405ce.html.

22 See Citizenship \& immigration Canada, Report on Plans and Priorities 2003-2004, Feb. 2003, available at: http://www.tbs-sct.gc.ca/est-pre/20032004/CI-CI/CI-CIr34_e.asp.
} 
being human is a sufficient precondition, whether in international law or in most domestic law frameworks.

In the Canadian Charter of Rights and Freedoms, only sections 3 (right to vote and be elected), 6 (right to enter and remain in the country) and 23 (minority language educational rights) specifically protect citizens. All other rights, including the right to equality and to not be discriminated against on the basis of national origin (Art. 15), should equally apply to all human beings under the purview of the Charter, and the Supreme Court has said that this means "every person physically present in Canada and by virtue of such presence amenable to Canadian law". ${ }^{23}$

Article 1 of the Canadian Charter of Rights and Freedoms prescribes a duty to protect rights and freedoms of everyone, except for limitations foreseen by the law, which are reasonable and justified in a free and democratic society. Until now, this test has been submitted to a strict interpretation in order to provide the largest scope of rights possible. I hope that, despite the pressures exerted upon them by the government and by public opinion, the courts will not alter their position simply because those who are involved in such cases are foreigners. We shall have to wait for the outcome of the courts' decisions on the constitutionality of many of the measures we mentioned, in order to have a better understanding of the situation.

Let us take the examples of the right to equality and the right to a fair trial, remembering that all human rights instruments should be given a generous interpretation in order to afford all persons the maximum protection, just as criminal provisions are, for the same reason, to be interpreted restrictively.

The right to equality before the law has often been interpreted as inapplicable to proceedings relating to foreigners in an irregular situation. ${ }^{24}$ The reasoning for such an exemption is that such proceedings do not correspond to anything to which a citizen could be subjected. If an effect-based interpretation is adopted, as favored by the

\footnotetext{
23 Singh v. Minister of Employment and Immigration, [1985] 1 S.C.R. 177.

24 See Chiarelli v. Canada (Minister of Employment and Immigration), [1992] 1 S.C.R. 711 ; Huynh

v. Canada (C.A.), [1996] 2 F.C. 976.
} 
Canadian Supreme Court in $A n d r e w s^{25}$ for example, there is no reason to distinguish the detention of a foreigner from any other person's detention since the effect of the detention in either case (i.e. the deprivation of physical liberty) is exactly the same. Deportation proceedings can also be interpreted by reference to their consequences. If the risk posed to an individual by particular proceedings is death, torture, detention, cruel, inhuman or degrading treatment, there is no reason to consider these proceedings of lesser seriousness than those which would subject citizens to similar treatment, such as extradition proceedings. The case law on the right to equality and the fight against discrimination is growing and foreigners should benefit from it.

The right to a fair trial, for its part, is still understood to apply only to criminal proceedings. The whole of the treatment applied to foreigners in an irregular situation such as detention or deportation, is still regarded as administrative procedure to which fair trial provisions do not apply. This is the case under the Canadian Charter of Rights and Freedoms. This interpretation comes from an era where administrative law was embryonic and therefore human rights instruments did not yet envisage its future development, much less its extreme impact on rights and freedoms. If more modern human rights instruments are considered, one can see that the fair trial provision is being expanded to cover all proceedings under the law, regardless of their criminal or administrative character. The recent Charter of Fundamental Rights of the European Union $^{26}$ (the E.U. Charter) does not make such a distinction. Article 47 of the E.U. Charter extends the "right to an effective remedy and to a fair trial" to "everyone whose rights and freedoms guaranteed by the law of the Union are violated". This includes a right to "a fair and public hearing within a reasonable time by an independent and impartial tribunal”, as well as a right to legal aid.

Domestic tribunals have not yet all met this challenge. Protecting the rights of foreigners today corresponds, mutatis mutandis, to protecting the rights of workers a hundred years

\footnotetext{
25 Andrews v. Law Society of British Columbia, [1989] 1 S.C.R. 143. In this case, the requirement of Canadian citizenship in order to become a lawyer has been deemed a discriminatory distinction, as citizenship did not add anything to the qualification or loyalty of the professional who would otherwise satisfy the criteria for becoming a lawyer.
}

26 Charter of Fundamental Rights of the European Union, O.J.E.C. 2000/C364/01, Dec. 18, 2000. 
ago, the rights of women fifty years ago, the rights of Aboriginals twenty-five years ago or the rights of gays and lesbians nowadays. In their time, all of these categories were considered outside the circle of citizenship or legality, were deemed legal minors to be dealt with as objects, not respected as subjects of the law.

Courts take time to come to terms with such difficult social issues, but no less time than the whole of society. Courts can be a little ahead of their society and help it understand the complex implications of the rights that citizens have come to recognize as essential to their own dignity, to their own sense of self.

Whether foreigner or citizen, we are all deserving of justice when our fundamental rights are at stake. And, we are all deserving of the same justice, in quite the same way as we have finally admitted that, in the criminal system, the guilty and the innocent have the same right to justice.

We should continue to defend the modern conception of the law according to which the protection of fundamental rights outweighs the Raison d'État, unless it is justified by a national emergency situation.

The protection of Canadian citizens cannot be based on the denial of foreigners' rights. The same rights are at stake: the violation of a foreigner's rights is a violation of a citizen's rights.

It took us time to understand that the fight against crime could not be legitimately held unless we respected the rights of the accused and we accepted that it was more important not to jail an innocent, than to let a criminal escape punishment.

Likewise, the fight against terrorism is a primary political and social objective of our States and should be conducted with all the necessary means, which include security intelligence, counter-espionage, police operations, arrests, detentions, etc.

Nevertheless, this is not a fight at any cost. The fight against terrorism, in order to be legitimate in the long run, should be subordinated to the protection of the rights of any suspect, including a suspected foreigner.

During the last decades, foreigners have progressively obtained most of what criminals got in the 19th century, that is, the recognition that their rights will prevail upon the State's interests. 
We acknowledged, in 1982, that the protection of the fundamental rights prevailed upon parliamentary sovereignty, that democratically elected persons cannot do anything they want, that the legitimacy of a collective act depends on the respect of everyone's fundamental rights.

If we make now an exception for foreigners to this key element of the Rule of Law, other exceptions might be accepted tomorrow: arguably, nothing would prevent restricting the rights of socially disabled persons if the State declared this would be in our interest. Our shared humanity is based upon the principle of equality. The Canadian courts have made themselves the champions of this conception of the right to equality and Canada has projected the image of a country preoccupied with human rights, human dignity and the "duty to protect", included in the Human Security Agenda promoted by Canada

Our openness to immigration and our fundamental commitment to respecting human rights are essential elements of the image that Canada projects abroad, an image all Canadians are proud of. Canada's International Policy Statement, recently released ${ }^{27}$, is full of this rhetoric. We are still considered as a country that cares for and respects human rights for all. But some of our policies towards migrants could start denting that image. Certainly, the Maher Arar case is troubling enough. The debate around security certificates will continue: the need for them can be demonstrated but the conditions of their implementation will need better human rights guarantees. Discrimination in other immigration policies will be invoked and discussed, such as the one mentioned in the Globe \& Mail of May $10^{\text {th }}$, where a Canadian citizen invoked the Charter to blast the decision of CIC to reject, by reason of an 'excessive demand' on the health system, his sponsorship application for his 73 year old non insuline dependant diabetic mother ${ }^{28}$.

Lest we reconsider the rights that foreigners are recognized in this country, in relation to those enjoyed by citizens, we risk loosing the moral high ground that we have enjoyed in the past decades.

\footnotetext{
27 Foreign Affairs Canada, A Role of Pride and Influence in the World, Canada's International Policy Statement, April 2005, http://www.dfait-maeci.gc.ca/cip-pic/ips/ips-en.asp Marina Jimenez, "Diabetic prevented from moving to Canada », Globe \& Mail, May 10 $0^{\text {th }}, 2005$, p.
} A8. 


\section{CONCLUSION}

In conclusion, I would argue that, today, we should accept that, in the international arena, a State cannot invoke anymore its territorial sovereignty to justify a systemic breach of fundamental human rights, of a foreigner as of a citizen.

It is true that international law does not yet recognize the absolute pre-eminence of fundamental rights upon State sovereignty, whereas this is considered to be an essential feature of domestic law in all democracies governed by the Rule of Law.

It is also true that the events of September $11^{\text {th }}$ have frightened us to a point that some people may have invoked the opportunity to establish torture certificates ${ }^{29}$, even if the absolute prohibition of torture is one of the most valuable legacies of the generation that lived through the atrocities of the Second World War and the Shoah.

Our current fear should not let us forget that, citizen or foreigner, we all are equally deserving of justice and that the necessary fight against terrorism cannot be made to the detriment of our system of protection of fundamental rights. This system is a common good to us all and an essential attribute of our civilization based, since 1945, on the absolute pre-eminence of human dignity.

\footnotetext{
29 Alan M. Dershowitz, "Want to torture? Get a warrant", San Francisco Chronicle, January 22, 2002, http://www.sfgate.com/cgi-bin/article.cgi?file=/chronicle/archive/2002/01/22/ED5329.DTL.
} 